Nowe kierunki w zarządzaniu przedsiębiorstwem.

Procesy i projekty w zarządzaniu zmianami

ISSN 1899-3192

e-ISSN 2392-0041

\title{
Janusz Kraśniak
}

Uniwersytet Ekonomiczny w Poznaniu

e-mail: janusz.krasniak@ue.poznan.pl

\section{W KIERUNKU ORGANIZACJI PROCESOWEJ. DETERMINANTY WDRAŻANIA \\ IN THE DIRECTION OF THE PROCESS \\ ORGANIZATION. DETERMINANTS \\ OF THE IMPLEMENTATION}

DOI: $10.15611 /$ pn.2017.463.15

\begin{abstract}
Streszczenie: W artykule zaprezentowano wyniki postępowania badawczego zmierzającego do identyfikacji determinant skutecznego wdrażania organizacji procesowej. Przedstawiono także założenia i istotę organizacji procesowej. Na podstawie ankiet skierowanych do kierownictwa przedsiębiorstw produkcyjnych deklarujących wdrażanie organizacji procesowej zidentyfikowano determinanty ich skutecznego wdrażania. Do czynników ułatwiających wdrażanie organizacji procesowej zaliczano najczęściej: dostęp przedsiębiorstw do nowoczesnych technologii informatycznych, wielkość przedsiębiorstwa, identyfikację klientów wewnętrznych i zewnętrznych oraz prawidłową identyfikację przebiegu procesów w przedsiębiorstwie. Natomiast czynniki postrzegane jako najbardziej utrudniające wdrażanie organizacji procesowej zdaniem badanych to: centralizacja uprawnień decyzyjnych, stały charakter zespołów procesowych (jakości), opór kadry kierowniczej przeciwko zmianom struktury organizacyjnej oraz poziom przygotowania merytorycznego kadry kierowniczej.
\end{abstract}

Słowa kluczowe: organizacja procesowa, determinanty wdrażania, przedsiębiorstwo.

Summary: The article presents the concept of process-oriented organization and some conclusions of the research. The factors that determine the effectiveness of process organization were identified as the following: the size of an enterprise, the level of using information technology, the identification of customers, the correct identification of the process course. The centralization of decision-making, permanent character of process teams (quality), management opposition against organization change and the level of the management background are the barriers of the implementation of process organization.

Keywords: process organization, determinants of implementation, eneterprise.

\section{Wstęp}

Zauważalną tendencją ostatnich lat jest odchodzenie od tradycyjnego podejścia do zarządzania przedsiębiorstwem i uprzywilejowanie podejścia procesowego, co prze- 
jawia się m.in. upowszechnianiem organizacji procesowej. Dotychczasowe strategie związane z wykorzystaniem tradycyjnego podejścia, takie jak: nadawanie organizacji cech względnej stałości, jednoznaczna specjalizacja, precyzyjna koordynacja czy daleko idąca formalizacja, straciły na znaczeniu i nie stanowią już potencjału, który mógłby przyczynić się do zbudowania przewagi konkurencyjnej. Zaczęto zatem poszukiwać rozwiązań, które pozwolą budować właściwą pozycję konkurencyjną. Szczególna uwaga została zwrócona na podejście procesowe prowadzące do wyłonienia organizacji procesowej, w której poszczególne jej elementy wyodrębniane są na podstawie podobieństwa realizowanych procesów [Raport 2016]. Uważa się, że organizacja procesowa pozwala przezwyciężyć trudności związane z rosnącą turbulencją otoczenia, całościową obsługą klienta, koordynacją działań tworzących procesy, rewolucyjnym postępem $\mathrm{w}$ dziedzinie produktów i technologii, a tym samym kreować sukces i rozwój przedsiębiorstwa. Istotne zatem stają się badania dotyczące uwarunkowań skutecznego wdrażania organizacji procesowej, zwłaszcza w kontekście jej strukturalnych aspektów. Skuteczne wdrażanie obejmuje ogół działań, które przyczyniają się do nadawania organizacji przedsiębiorstwa cech organizacji procesowej.

Wychodząc z powyższych założeń, za cel opracowania przyjęto identyfikację uwarunkowań skutecznego wdrażania organizacji procesowej.

\section{Cechy właściwe organizacji procesowej}

Złożoność i specyfika procesów realizowanych przez przedsiębiorstwo sprawia, że najbardziej charakterystycznymi elementami organizacji procesowej są właściciele procesów oraz zespoły procesowe. M. Hammer stwierdza, że „różnica między organizacją procesową a tradycyjną przejawia się najwyraźniej w istnieniu właściciela procesu" [Hammer, Stanton 2000, s. 30]. Członkowie zespołu procesowego ponoszą odpowiedzialność za wykonanie całego procesu, a nie za realizację jego poszczególnych fragmentów. Nawet jeżeli członkowie wykonują zróżnicowane zadania uwzględniające ich kwalifikacje i uzdolnienia, ,...to każdy z nich przynajmniej w podstawowym zakresie powinien znać wszystkie etapy i fazy całego procesu i umieć realizować co najmniej niektóre z nich. Rozszerza się nie tylko postrzeganie zakresu pracy zawodowej, lecz także sekwencja faktycznie wykonywanych czynności. W konsekwencji ich praca zostaje wzbogacona" [Martyniak 1996, s. 332].

Istotną cechą organizacji procesowej jest ograniczanie liczby poziomów hierarchicznych, co wiąże się z zasadą minimalizowania liczby stanowisk kierowniczych i jest następstwem odchodzenia od funkcjonalnego podziału pracy. Stopniowo eliminuje się wieloszczeblowy układ hierarchiczny, którego głównym zadaniem jest rozstrzyganie konfliktów i uzgadnianie współdziałania między funkcjonalnymi obszarami przedsiębiorstwa. Powstaje w ten sposób struktura płaska, złożona z samodzielnych zespołów procesowych w pełni odpowiedzialnych za realizowane procesy. Dotychczasowi kierownicy funkcjonalni zajmują często miejsca jako specjaliści w ramach zespołów procesowych [Chang 2006]. 
Sprawne funkcjonowanie organizacji procesowych wymaga także zapewnienia właściwego stopnia standaryzacji procesów. M. Hammer i S. Stanton stwierdzają, że „...dobrze jest maksymalnie standaryzować procesy działalności, ale tylko do tego stopnia, by nie ograniczać zaspokajania zróżnicowanych potrzeb klientów”.

Standaryzacja procesów zapewnia liczne korzyści:

- ogranicza koszty administracyjne. $Z$ obsługą danego procesu może być związany jeden właściciel procesu wraz z zespołem procesowym, wykorzystujący jeden zestaw dokumentacji i materiałów szkoleniowych oraz korzystający z jednego systemu informatycznego,

- pozwala na wzrost elastyczności działania. W sytuacji gdy wszystkie jednostki organizacyjne przedsiębiorstwa funkcjonują w podobny sposób, łatwo można przenosić pracowników do innych jednostek, by reagować np. na zmiany popytu.

Tabela 1. Cechy organizacji procesowej

\begin{tabular}{|l|l|}
\hline $\begin{array}{l}\text { Wymiary strukturalne } \\
\text { organizacji }\end{array}$ & \multicolumn{1}{|c|}{ Charakterystyka } \\
\hline Konfiguracja & $\begin{array}{l}\text { Podstawowe elementy: } \\
-\quad \text { właściciel procesu } \\
-\quad \text { zespoły procesowe } \\
\text { Ograniczenie liczby szczebli hierarchicznych } \\
\text { Dominacja więzi technicznych } \\
\text { Dominujący poziomy kierunek przepływu informacji }\end{array}$ \\
\hline Centralizacja & $\begin{array}{l}\text { Decentralizacja uprawnień decyzyjnych (empowerment) } \\
\text { Dominacja relacji horyzontalnych nad hierarchicznymi } \\
\text { Odpowiedzialność za faktyczne rezultaty pracy mierzona stopniem } \\
\text { zaspokojenia potrzeb klienta }\end{array}$ \\
\hline Specjalizacja & $\begin{array}{l}\text { Odchodzenie od funkcjonalnego podziału pracy } \\
\text { Podstawą podziału pracy (tworzenia zespołów procesowych) są procesy } \\
\text { Proste zadania zastępowane są złożoną pracą wielowymiarową } \\
\text { Orientacja na zaspokojenie potrzeb klienta }\end{array}$ \\
\hline Formalizacja & $\begin{array}{l}\text { Niski stopień formalizacji } \\
\text { Podstawowe dokumenty organizacyjne: } \\
- \text { mapa procesów } \\
- \text { karta procesów } \\
- \text { zestawienie czasu realizacji procesów }\end{array}$ \\
\hline Standaryzacja & $\begin{array}{l}\text { Standaryzacja procesów w stopniu pozwalającym na zaspokajanie } \\
\text { zróżnicowanych potrzeb klientów } \\
\text { Wielowariantowość procesów }\end{array}$ \\
\hline
\end{tabular}

Źródło: opracowanie własne.

Z drugiej strony odchodzenie od standaryzacji poprzez zapewnienie swobody pracownikom w sposobie realizacji procesów (samodzielne tworzenie procedur realizacyjnych) umożliwia obsługiwanie klientów w sposób zapewniający maksymalne zaspokojenie ich potrzeb. Odchodzenie od standaryzacji zmienia role pracownika: 
$\mathrm{z}$ biernego wykonawcy w aktywnego realizatora, zdolnego do niekonwencjonalnych działań wyznaczonych złożonością procesu, za który odpowiada.

Dylemat związany z zapewnieniem właściwego stopnia standaryzacji rozwiązać można poprzez wprowadzenie wielowariantowości procesów. Wielowariantowość procesów zapewnia ich dostosowanie do wymagań poszczególnych rynków i klientów.

Mapę procesów należy uznać za jeden z najważniejszych dokumentów, regulujących zachowanie członków organizacji procesowych i potwierdzających fakt wdrażania tych organizacji. Innymi ważnymi dokumentami związanymi z funkcjonowaniem organizacji procesowych są dokumenty opisujące przebieg procesów, np. karta procesów czy zestawienie czasów realizacji procesów. Charakteryzuje je różny poziom szczegółowości uzależniony od istoty opisywanych procesów.

Zbiorcze zestawienie cech organizacji procesowej zawiera tabela 1.

Organizacje wdrażające podejście procesowe przechodzą zwykle przez kilka określonych stadiów, dla których charakterystyczne są: struktura funkcjonalna, struktura funkcjonalna $\mathrm{z}$ wyodrębnionymi procesami, struktura procesowa z zachowanym układem funkcjonalnym i horyzontalna struktura procesowa. Każde kolejne stadium rozwoju organizacji procesowej oferuje zwiększający się stopień skupienia działań członków organizacji na procesach i odchodzenie zarazem od działań zorientowanych na realizację funkcji. Prowadzi to do wykorzystywania w procesie departamentalizacji organizacji w szerszym zakresie kryterium funkcjonalnego bądź procesowego [Nippa, Picot 2005; Nowosielski 2007, s. 26-32].

\section{Charakterystyka próby badawczej}

Identyfikacja uwarunkowań skuteczności wdrażania organizacji procesowych w przedsiębiorstwie w warstwie empirycznej oparta jest na analizie odpowiedzi do ankiety skierowanej do jednostek gospodarczych zarejestrowanych w systemie REGON.

Postępowaniem badawczym objęto 455 jednostek gospodarczych. Ograniczono się do przedsiębiorstw należących w Europejskiej Klasyfikacji Działalności do grupy działalność produkcyjna, posiadającej kody od 15 do 37. Badanie to nie objęło mikroprzedsiębiorstw, zatrudniających do 9 pracowników. W postępowaniu badawczym przyjęto założenie, że w badanej grupie przedsiębiorstw upowszechnianie podejścia procesowego i związanej z nim idei organizacji procesowej jest istotnym czynnikiem przyczyniającym się do wzrostu sprawności ich funkcjonowania i budowania przewagi konkurencyjnej. Do kierownictwa wszystkich jednostek objętych badaniem wysłano ankiety. Dla całego badania zwrot ankiet wyniósł 21,5\% (98 ankiet).

\section{Wyniki postępowania badawczego}

Wśród czynników, które wymusiły zmiany polegające na nadawaniu organizacji cech organizacji procesowej w skali całej badanej zbiorowości i całego badanego 
okresu, jako te, które oddziaływały w największym stopniu, wymieniano najczęściej (w kolejności malejącej):

- wymagania klienta,

- strategia przedsiębiorstwa,

- konkurenci,

- rynek pracy,

- czynniki prawne.

W badanych jednostkach najczęściej wykorzystywanym dominującym kryterium rozdziału zadań między stanowiska i komórki organizacyjne w przedsiębiorstwie okazało się kryterium według funkcji (np. produkcja, zaopatrzenie, sprzedaż itp.). Kryterium to wskazało ponad $90 \%$ wszystkich badanych jednostek; $21 \%$ badanych jednostek jako kryterium rozdziału zadań stosuje produkt, region, $13 \%$ klienta, natomiast 7\% wskazało na procesy. Wyniki potwierdzają - mimo rosnącej popularności podejścia procesowego - dominację tradycyjnych rozwiązań organizacyjnych [Nowosielski 2012, s. 160].

Prawie $60 \%$ ankietowanych określa organizację ich jednostki jako scentralizowaną, przy czym za kontakty z klientami kluczowymi najczęściej odpowiedzialny jest szczebel średni kierownictwa (53,4\% badanych) i najwyższy $(44,7 \%)$. Natomiast za kontakty z pozostałymi klientami najczęściej odpowiada średni $(65,2 \%)$ lub najniższy szczebel kierownictwa (30,3\%). Najwyższy szczebel też ma swój udział w kontaktach z pozostałymi klientami (ok. $4,5 \%$ ).

W zakresie sposobu koordynacji (uzgadniania) współdziałania podległego personelu w przedsiębiorstwie najczęściej stosuje się:

- przekazywanie poleceń do wykonania $(36,7 \%)$,

- wspólne z podwładnymi ustalanie planów i celów do osiągnięcia $(25,1 \%)$,

- zbiór reguł i procedur $(22,9 \%)$,

- zebrania pracowników $(10,0 \%)$,

- kolegia, komisje i komitety $(5,4 \%)$.

Zidentyfikowane sposoby koordynacji wskazują na hierarchię jako główny sposób uzgadniania współdziałania podwładnych. Potwierdza to tendencje skupiania uprawnień decyzyjnych na najwyższych szczeblach zarządzania przedsiębiorstwem.

Technologie informatyczne w badanych przedsiębiorstwach najczęściej wykorzystuje się do działań określanych mianem „gospodarka magazynowa”, a także do bezpośrednich kontaktów z klientem. W dalszej kolejności wskazywano kontakty z dostawcami oraz wspieranie procesów decyzyjnych i controllingu. Najrzadziej natomiast wykorzystywano IT w celu dostosowania produktów do indywidualnych potrzeb klienta oraz do wspierania realizacji procesów głównych i pomocniczych.

Wśród form zespołowej organizacji pracy ankietowane jednostki wymieniały różne konfiguracje podanych w ankiecie możliwości. Najczęściej wymieniano zespoły projektowe oraz komitety i komisje, w skład których wchodzą pracownicy różnych działów. W dalszej kolejności wymieniane były zespoły procesowe, koła jakości i inne. Innymi formami zespołowej organizacji pracy były najczęściej: działy, brygady, 
zespoły wydziałowe itp. Dominującą konfiguracją wśród badanych przedsiębiorstw było występowanie w jednostce jednocześnie komitetów i komisji złożonych z pracowników różnych działów, zespołów projektowych i zespołów procesowych - prawie $7 \%$. Analiza odpowiedzi na pytanie o dominujące formy zespołowej organizacji pracy w przedsiębiorstwie pozwala także na sformułowanie wniosku, że spośród 98 przebadanych przedsiębiorstw $38 \mathrm{z}$ nich stosuje do rozwiązywania pojawiających się problemów okresowe spotkania przedstawicieli różnych działów (np. pionów funkcjonalnych) - co wskazywać może na wykorzystywanie struktury funkcjonalnej $\mathrm{z}$ wyodrębnionymi procesami. Wyniki te nieznacznie różnią się od wyników badań przeprowadzonych przez BCG, dotyczących powszechności występowania różnych rozwiązań strukturalnych. Według BCG struktura funkcjonalna $\mathrm{z}$ wyodrębnionymi procesami charakterystyczna była dla $38 \%$ przebadanych przedsiębiorstw.

Wśród procesowych koncepcji zarządzania wykorzystywanych w badanych przedsiębiorstwach dominuje TQM $(77,2 \%)$. Jako drugą najczęściej wymienia się zarządzanie procesowe (prawie 14,1\%), następnie BPR i inne formy (po 4,4\%).

Nadawanie organizacji cech organizacji procesowych w zdecydowanej części badanych przedsiębiorstw odbywało się w sposób ewolucyjny (90\%). W pozostałej części zmiany te miały gwałtowny charakter, określany przez ankietowane przedsiębiorstwa jako rewolucyjny. Charakterystyczne przy tym jest to, że w prawie $79 \%$ badanych jednostek, które wdrażały organizacje procesowe, wdrożenie to było poprzedzone etapem opracowania projektu. Jednakże $21 \%$ nie opracowało wcześniej projektu. W pracach wdrożeniowych i projektowych korzystano z pomocy konsultantów zewnętrznych. Minimalnie większy udział konsultantów zewnętrznych miał miejsce na etapie opracowania projektu (75\%), podczas gdy ich udział w pracach związanych $\mathrm{z}$ wdrożeniem projektu spadał do ok. $71 \%$. $Z$ analizy powyższych danych wynika, że wdrożenie założeń organizacji procesowych ze względu na charakter, specyfikę i zakres niezbędnych zmian traktowane jest jako przedsięwzięcie wymagające udziału konsultantów zewnętrznych. Konieczność ta wynika także często z wymogów formalnych, np. wdrożenie norm ISO 9000 wymaga nadania przez niezależne instytuty certyfikatów jakości.

Rozkład liczby procesów głównych zidentyfikowanych w badanych przedsiębiorstwach cechuje się bimodalnością. Można wyodrębnić dwa ośrodki dominujące: przedsiębiorstwa, gdzie zidentyfikowano tylko 1 proces główny $(30,5 \%)$, i przedsiębiorstwa, gdzie zidentyfikowano 7 procesów głównych (19\%). Pozostałe warianty mają mniej więcej stały odsetek wskazań, który wynosi ok. 10\%.

Analizując odpowiedzi na pytanie dotyczące wprowadzenia wielowariantowości realizowanych procesów, należy zauważyć, że $40 \%$ badanych jednostek nie wprowadziło wielowariantowości procesów.

Wśród badanych jednostek wszystkie deklarują odzwierciedlenie zidentyfikowanych procesów w istniejącej dokumentacji. Przeważały jednostki, gdzie procesy te mają odzwierciedlenie w procedurach. Następnymi rodzajami dokumentów, które najczęściej występują w odpowiedzi na to pytanie, są instrukcje i księga jakości. Mapę 
procesów wykorzystuje 70,2\% przedsiębiorstw wdrażających koncepcje zarządzania procesowego. Dokument ten należy uznać za charakterystyczny dla organizacji procesowej, ponieważ wyłącznie przedsiębiorstwa wdrażające organizacje procesowe zadeklarowały posiadanie mapy procesów.

Badane jednostki najczęściej wskazywały kierowników najwyższego szczebla jako właścicieli procesów (58\% wskazań). Kierownicy średniego szczebla byli wskazywani jako właściciele procesów w ok. 36\%.

W $64,5 \%$ badanych jednostek zespoły procesowe mają stały charakter, tzn. spotkania członków zespołów procesowych odbywają się regularnie i mają charakter formalny (są przyjętym obowiązującym sposobem działania). W pozostałych jednostkach zespoły procesowe miały charakter tymczasowy.

Analiza czynników, które w opinii kierowników przedsiębiorstw wspierają lub przeszkadzają we wdrażaniu organizacji procesowych w przedsiębiorstwie, pokazuje, że wśród czynników ułatwiających w dużym stopniu najczęściej wymieniane są:

- postęp naukowo-techniczny,

- wielkość przedsiębiorstwa,

- udział w pracach projektowych i wdrożeniowych konsultantów zewnętrznych,

- dostęp przedsiębiorstwa do nowoczesnych technologii informatycznych,

- identyfikacja klientów wewnętrznych i zewnętrznych,

- wiek przedsiębiorstwa,

- prawidłowa identyfikacja przebiegu procesów w przedsiębiorstwie.

Natomiast czynnikami, które zajmują ostatnie miejsce wśród czynników postrzeganych jako ułatwiające, są:

- czynniki polityczne,

- czynniki prawne,

- własność kapitału,

- wielkość przedsiębiorstwa.

Czynniki postrzegane natomiast jako najbardziej utrudniające wdrażanie organizacji procesowej to w kolejności wg liczby wskazań:

- centralizacja uprawnień decyzyjnych,

- kultura organizacyjna,

- stały charakter zespołów procesowych (jakości),

- opór kadry kierowniczej przeciwko zmianom struktury organizacyjnej,

- poziom przygotowania kadry kierowniczej,

- czynniki prawne,

- nadmierna formalizacja.

Należy tu zwrócić uwagę na fakt, że postrzeganie danego czynnika może mieć dwoisty charakter. Na przykład poziom przygotowania pracowników może być czynnikiem ułatwiającym, jak i utrudniającym wdrażanie organizacji procesowych. Jeżeli mamy do czynienia z wysokim poziomem przygotowania pracowników, będzie on wtedy niewątpliwie czynnikiem ułatwiającym, w przypadku natomiast niskiego poziomu przygotowania pracowników jest elementem utrudniającym wdrażanie założeń organizacji procesowej. 


\section{Zakończenie}

Wyniki przeprowadzonych badań i analiz pozwoliły zidentyfikować uwarunkowania skuteczności wdrażania organizacji procesowej. Uwarunkowaniami tymi są: wielkość przedsiębiorstwa, udział w pracach projektowych i wdrożeniowych konsultantów zewnętrznych, dostęp przedsiębiorstwa do nowoczesnych technologii informatycznych, identyfikacja klientów wewnętrznych i zewnętrznych, prawidłowa identyfikacja przebiegu procesów w przedsiębiorstwie i wiek przedsiębiorstwa. Wyniki badań wskazują, że podstawowymi barierami wdrożenia organizacji procesowej są bariery organizacyjne (centralizacja i kultura organizacyjna), bariery społeczne (opór pracowników i kadry kierowniczej wobec zmian) oraz przygotowanie merytoryczne kadry kierowniczej. Świadczyć to może o tym, że decyzji o wdrożeniu organizacji procesowej nie poprzedza się odpowiednim przygotowaniem organizacji i pracowników. Nie stwarza się warunków do współuczestnictwa, nie uświadamia pracownikom potrzeby zmian oraz nie zapewnia systemu otwartej komunikacji i informacji.

\section{Literatura}

Chang J.F., 2006, Business Process Management Systems, Auerbach, New York.

Hammer M., Stanton S., 2000, How process enterprises really work, Harvard Business Review - Zarządzanie na Świecie, nr 1, s. 30.

Martyniak Z., 1996, Metody organizowania procesów pracy, PWE, Warszawa.

Nippa M., Picot A., 2005, Prozeßmanagement und Reengineering. Die Praxis im deutschsprachigen Raum, Campus Verlag, Frankfurt-New York.

Nowosielski S., 2007, Aspekty procesowe w rozwoju organizacji, Przedsiębiorczość i Zarządzanie, Rozwój organizacji - nauka dla praktyki gospodarczej i samorzadowej, t. VIII, zeszyt 2, red. J. Lichtarski, SWSPiZ, Łódź.

Nowosielski S., 2012, Orientacja procesowa w organizacjach - teoria i praktyka, [w:] Metody badania i modele rozwoju organizacji, red. A. Stabryła, S. Wawak, Mfiles.pl, Kraków.

Raport. Dojrzałość procesowa polskich organizacji 2013, www.procesowcy.pl (maj 2016).

Rummler G.A., Brache A.P., 2000, Podnoszenie efektywności organizacji. Jak zarzadzać „, białymi plamami" w strukturze organizacyjnej?, PWE, Warszawa. 